\title{
Uveitis associated to the infection by Leishmania chagasi in dog from the Olinda city, Pernambuco, Brazil
}

\author{
Uveíte associada à infecção por Leishmania chagasi em cão \\ na cidade do Olinda, Pernambuco, Brasil
}

\begin{abstract}
Fábio Luiz da Cunha Brito ${ }^{1}$ Leucio Câmara Alves ${ }^{2}$ Juan Pablo Duque Ortiz ${ }^{3}$ Federico Celso Lyra Maia ${ }^{4}$ Valdemiro Amaro da Silva Junior ${ }^{4}$ Jose Luiz Laus $^{5}$
\end{abstract}

\section{- CASE REPORT -}

\section{ABSTRACT}

Among the parasitic diseases, Canine Visceral Leishmaniasis (CVL) is included in the systemic illnesses of chronic evolution that attack men and dogs, presenting varied clinical manifestations as cachexia, dermatologic lesions, peripheral lymphadenopathies, besides the ocular lesions. This work report the case of a dog clinically suspected of having CVL, presenting skin lesions, cachexia, gryphosis, and ocular signs of uveitis. The parasitological diagnosis was accomplished for Canine Leishmaniasis through the visualization of amastigote forms of Leishmania chagasi in smears of bone marrow fluid aspirate, of non-lesioned, and lesioned skin. Alterations in the ocular structures are characterized mainly by mononuclearplasmocitic infiltrate.

Key words: uveitis, Leishmania sp, dog.

\section{RESUMO}

Dentre as doenças parasitárias, a Leishmaniose Visceral Canina (LVC) inclui-se entre as enfermidades sistêmicas de evolução crônica que acometem seres humanos e cães, suscitando nessa última espécie, manifestações clínicas variadas como caquexia, dermatopatias, linfadenopatias periféricas, além das lesões oculares. Neste trabalho, relata-se o caso de um cão com suspeita clínica de LVC, apresentando lesões dermatológicas, caquexia, grifose e sinais oculares de uveíte. Realizou-se diagnóstico parasitológico para leishmaniose canina através do encontro de formas amastigotas de Leishmania sp. Alterações nas estruturas oculares caracterizaram-se, principalmente, por infiltrado mononuclearplasmocitário.

Palavras-chave: uveíte, Leishmania sp, cão.

\section{INTRODUCTION}

The uveitis, which is defined as the inflammation of the uveal tract, is a component of most of the intraocular diseases. Its highly vascular nature and proximity with other intraocular structures make it a commonly found disease (COLLINS \& MOORE, 2003).

Uveitis is manifested by a wide variety of ocular signs (SLATTER, 1990). The systemic diseases have been reported as endogenous causes of uveitis. The Canine Visceral Leishmaniasis (CVL), or canine calazar (kala-azar), is included among the evolution diseases of zoonotic character (FEITOSA et al., 2000), potentially fatal, which attacks dogs, with clinical varied manifestations, including the ocular ones (MOLLEDA et al., 1993; GARCIA-ALONSO et al., 1996).

The ocular and histopathological alterations resulting from the CVL may affect the anterior and posterior segments of the eye (PUCHOL \&

${ }^{1}$ Graduate Student of Veterinary College, Federal University of Pernambuco (UFRPE), Recife, PE, Brazil.

${ }^{2}$ DVM, PhD, Professor of Veterinary College, Departament of Veterinary Medicine, UFRPE, Recife, PE, Brazil.

${ }^{3}$ Graduate Student of College of Veterinary and Agronomic Sciences (FCAV), Sao Paulo State University (UNESP), Jaboticabal, Sao Paulo, Brazil

${ }^{4}$ DVM, MSc., Professor of Veterinary College, Departament of Veterinary Medicine, UFRPE, Recife-PE, Brazil.

${ }^{5} \mathrm{DVM}$, PhD, Professor of the FCAV, UNESP. Author for correspondence, Via de Acesso Professor Paulo Donato Castellane, s/n, 14884900, Jaboticabal, Sao Paulo, Brazil. E-mail: jllaus@fcav.unesp.br 
GONZALEZ, 1989; Peña et al., 2000). The histopathological findings, in different degrees of intensity, are characterized by the infiltrate of inflammatory cells affecting several intraocular structures (MOLLEDA et al., 1993).

\section{CASE REPORT}

The authors report a case of a 5-year-old male Rhodesian ridgeback dog assisted at the Veterinary Hospital of Veterinary College, Federal Rural University of Pernambuco clinically suspected as having CVL originating from the city of Olinda in Pernambuco state. When examined, the animal presented gryphosis, cachexia, ulcerated skin lesions and anterior uveitis.

\section{RESULTS AND DISCUSSION}

The clinical diagnosis can be established based on the ocular signs, as ocular discharge, conjunctival hyperemia, chemosis and congested episcleral vessels (Figure 1), as it has been indicated by COLLINS \& MOORE (2003). The parasitological diagnosis was accomplished through the visualization of amastigote forms of Leishmania sp in smears of bone marrow fluid aspirate (Figure 2), and of nonlesioned, and lesioned skin. Due to the precarious clinical conditions and very unfavourable prognosis, the patient was sacrificed, and the eyes and adnexa were histopathologically evaluated.

On the third eyelid, the conjunctive tissue showed areas of mononuclear-plasmocitic infiltrate. Below the conjunctive, scaly metaplasia, which in some areas tried to surround groups of inflammatory cells, was observed. The third eyelid conjunctival epithelium presented scaly metaplasia, hyperplasy of the calciform cells, and mononuclear-plasmocitic subepithelial infiltrate (Figure 3). From the findings, only the inflammatory exsudation was similar to the reported by MOLLEDA et al. (1993). On the cornea, the separation of collagenous fibers was observed characterizing edema. Low quantity of plasmocites was observed. The anterior epithelium was hyperplasic with the subjacent conjunctival stroma and the Descemet Membrane thickened. The sclera showed areas with mononuclear-plasmocitic infiltrate (Figure 3 ). In the ciliary body and in the iris conjunctive edema with mononuclear-plasmocitic infiltrate and vascular dilatation of the lymphatic vessels and veins was

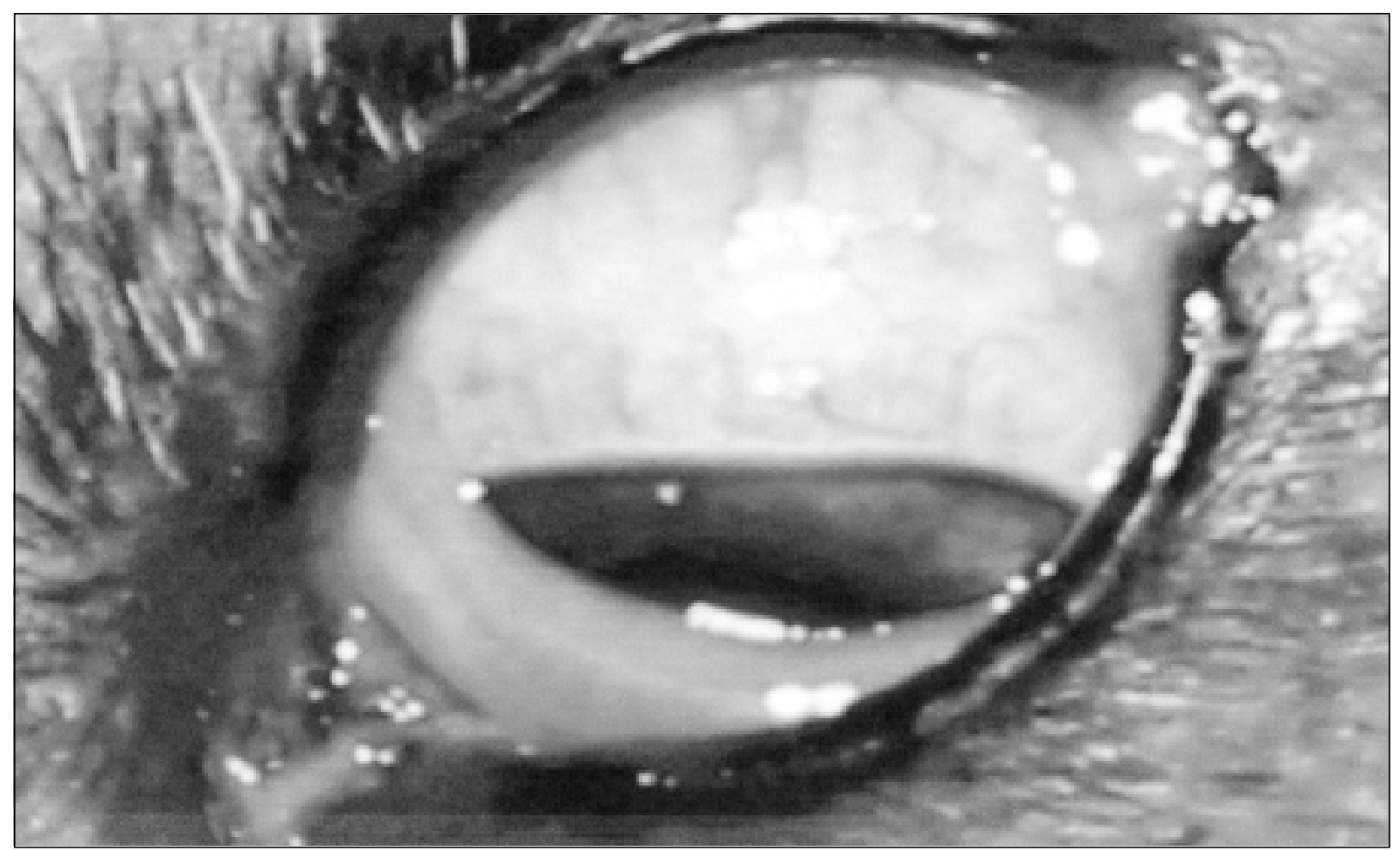

Figure 1 - Photographic image of dog eye with Leishmaniasis showing congested episcleral vessels, ocular discharge, anterior conjunctival and uveal hyperemia, parasitologically positive for Leishmania chagasi.

Ciência Rural, v.34, n.3, mai-jun, 2004. 


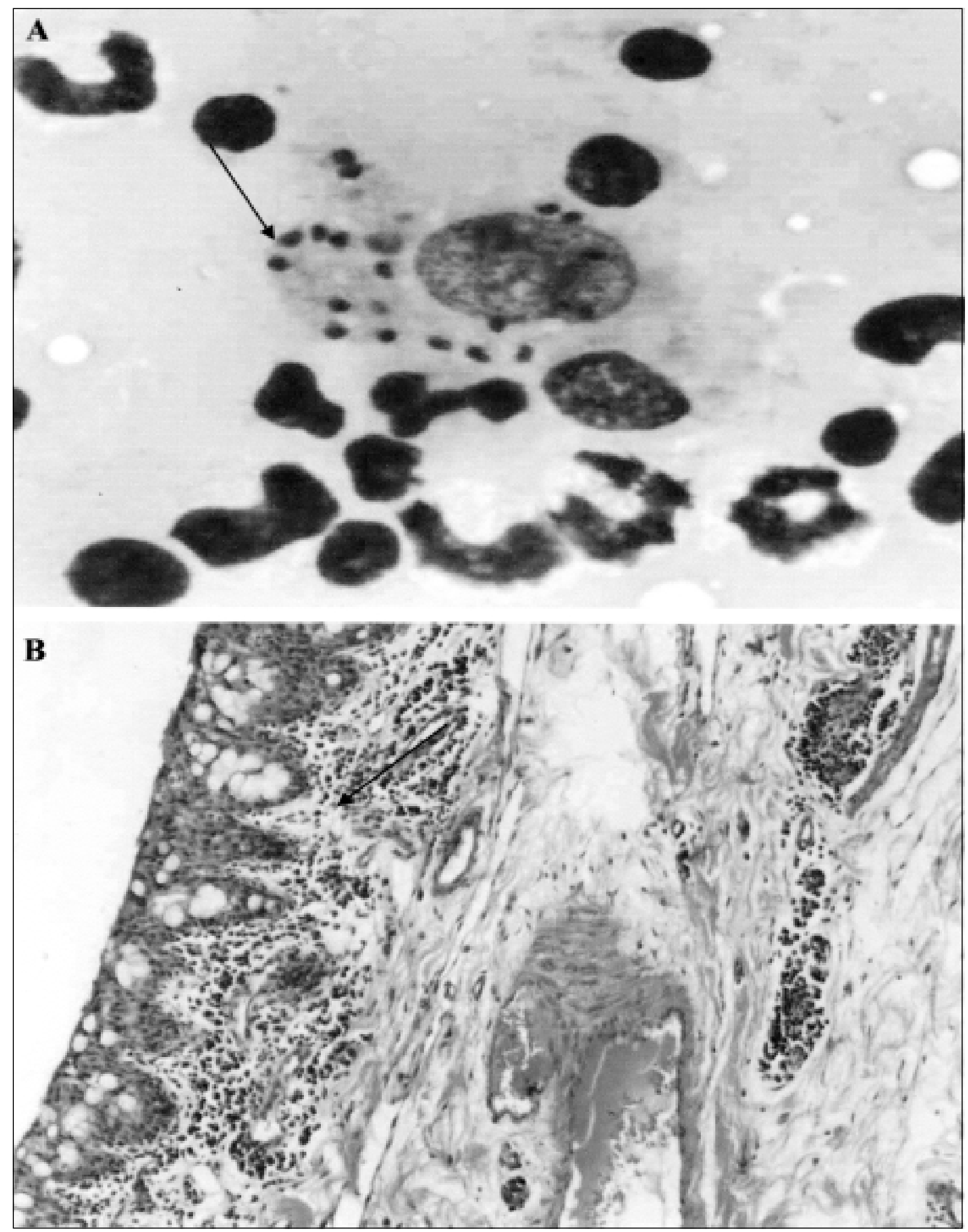

Figure 2 - A - Photomicrographic image of amastigote forms of Leishmania sp (arrow) parasiting macrophages, in smears of bone marrow fluid aspirate, stained Panotic. 1000x. B - Photomicrographic image of calciform cells hyperplasy with scaly metaplasia and mononuclear-plasmocitic subepithelial infiltrate conjunctive of the third eyelid. H\&E. 400x.

Ciência Rural, v.34, n.3, mai-jun, 2004. 


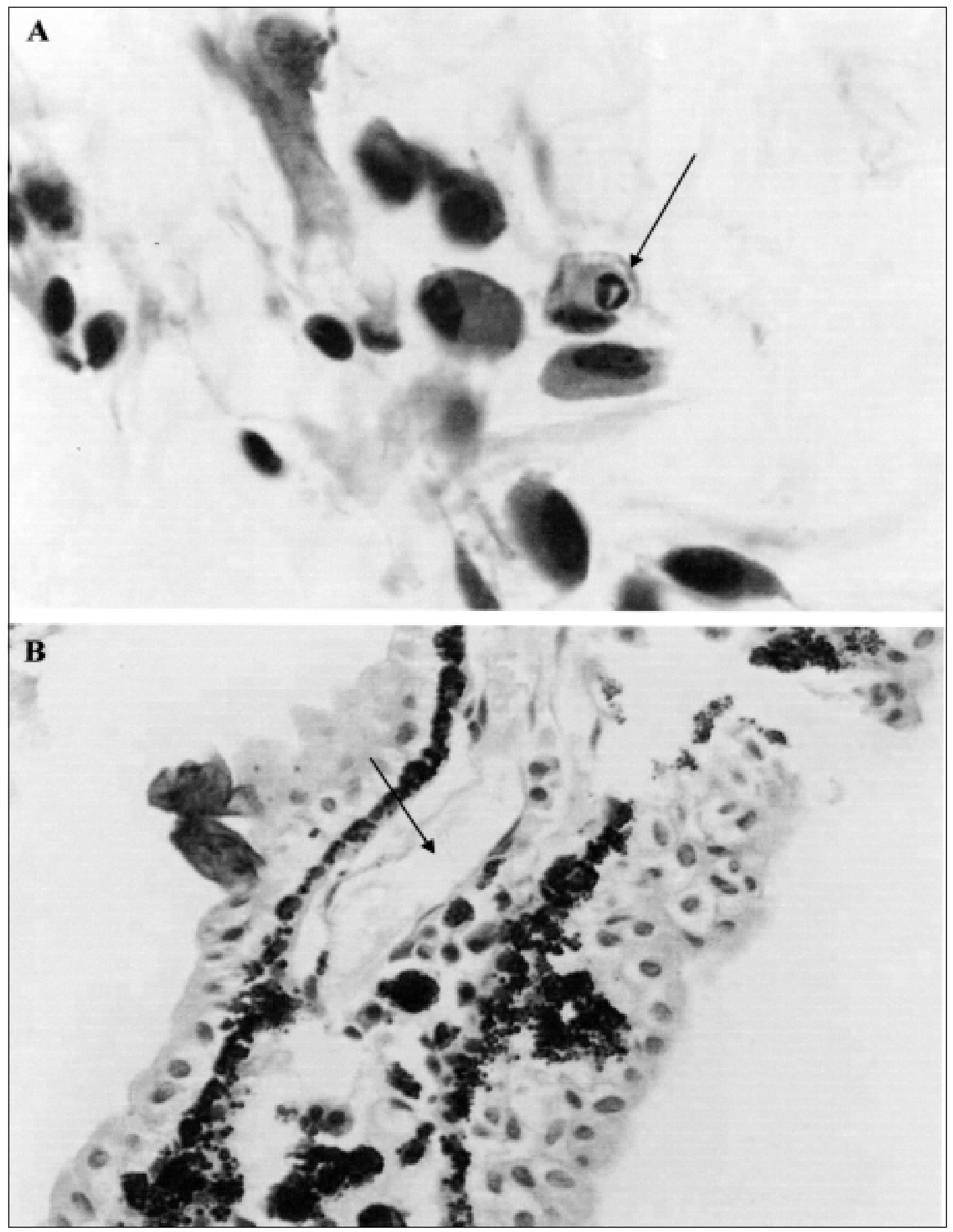

Figure 3 - A - Photomicrographic image of infiltrate showing cell of the mononuclear fagocitic system and plasmocites of the cornea. B Photomicrographic image of conjunctival edema and lymphatic vessels dilatation (arrow) of the iris. H\&E. 400x.

Ciência Rural, v.34, n.3, mai-jun, 2004. 
observed, as it has been shown by GARCIAALONSO et al. (1996), except for the conjunctive edema.

\section{CONCLUSIONS}

The observations ratify the obligation of including the disease in the differential diagnosis of other infectious diseases potentially able of causing uveitis.

\section{REFERENCES}

COLLINS, B.K.; MOORE, C.P. Doenças e cirurgia da úvea anterior do cão. In: GELATT, K.N. Manual de oftalmologia veterinária. Barueri : Manole, 2003. p.594.

FEITOSA, M.M. et al. Aspectos clínicos de cães com leishmaniose visceral no municipil de Araçatuba - São
Paulo (Brasil). Clínica Veterinária, v.28, p.36-42, 2000 .

GARCIA-ALONSO, M. et al. Immunopathology of the uveitis in canine leishmaniasis. Parasite Imunology, n.18, p.617-623, 1996.

MOLLEDA,J. M. et al. Clinical and histopathological study of the eye in canine leishmaniasis. Israel Journal of Veterinary Medicine, n.48, p.173-178, 1993.

PEÑA, M.T.; ROURA, X.; DAVIDSON, M.G. Ocular and periocular manifestations of leishmaniasis in dogs: 105 cases (1993-1998). Veterinary Ophthalmology, n.3, p.35-41, 2000.

PUCHOL, J.L.; GONZALEZ, J.L. Leishmaniasis ocular: afeciones del segmento anterior. In: NAT. CONG. Of AVEPA, Barcelona (Spain) p.115-122, 1989.

SLATTER, D. Fundamentals of veterinary ophtalmology. 2.ed. Philadelphia : Saunders, 1990. p.304-307. 